\section{仙台における丘陵地の宅地造成}

\section{杉 森 唯 史}

仙台周辺の丘陵地に打将方宅地造成は，最近 急速な発展をみせている。1955 年以降, 市の 北部扣よび西南部の丘陵地に打汸る宅地造成は 土地会社，山林地主，国鉄，共済組合，宮城県 住宅供給公社などによって行なわれている。そ の 90\% 以上の面積が土地会社など民間資本に よるもので, $30,000 \mathrm{~m}^{2}$ 以上の大規模な造成地 だけでも 42 個所に達し，いずれる山林を切り

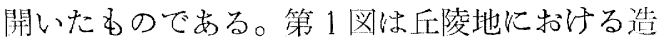
成宅地および造成中の地域とそこへ居住した世 带数を示したものである。

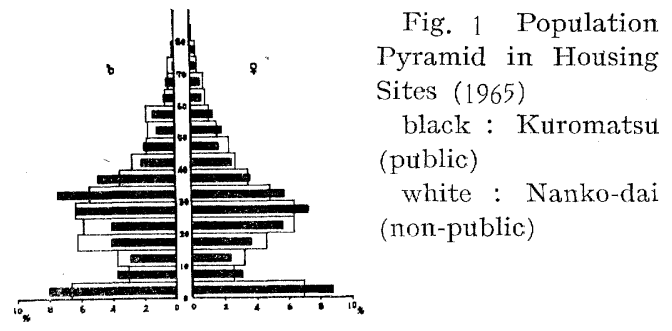

住宅地の造成虫市街地の外縁に連坦して建設 されるるのと，飛地的に建設されるるのとの 2 つのタイプに区分される。

北部の丘陵地では市街地の外縁に1957年から 造成が進められ，丘陵の緩かな北斜面が大規模 飞宅地化された。そのうち姐分丘虫130万 $\mathrm{m}^{2}$, そ の東に連続する南光台子 100 万 $\mathrm{m}^{2}$ 以上:の土地を 造成している。これらの発展は著るしく，その 膨張, 拡大と黒松団地 $\left(58\right.$ 万 $\left.\mathrm{m}^{2}\right)$ など飛地的に建 設された住宅地の発展とによって，この両地域 が連続し，広大な住宅地域を形成しつつある。

西南部の 丘陵地における 宅地造成は 1956 60 年に北斜面に打いて小規模に行なわれ，す でに市街地化し，次いで 1961 年以降に南斜面 の開発が急速に進み，とくに 1964 年以降は大 規模に造成が行なわれ，1965 年には飛地的な ものが西南にみられるようになった。

造成地に扣壮る住宅の建築は, 早くから造成 された方街地外縁部に多い。これ蛙民間資本に よる造成宅地は大部分が分讓地であるため, 上 地の購入後早くて2 -3年後に住宅が建築される ことによる。しかし，県住宅供給公社が建設する

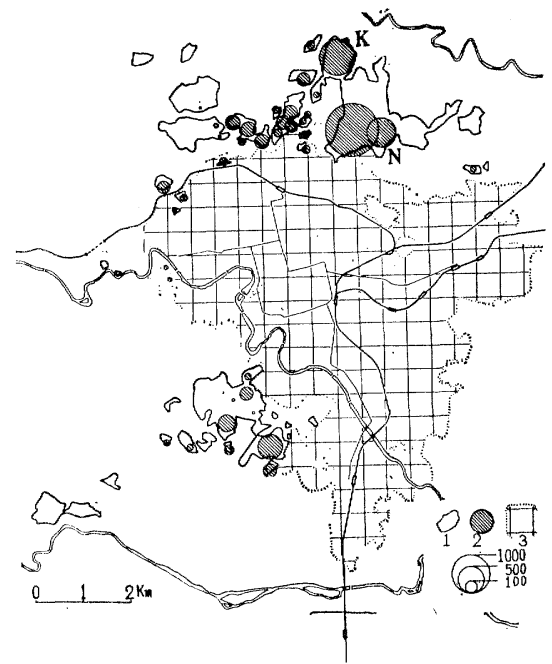

Fig. 2 Distribution of Housing Sites in Sendai

1. Housing sites

2. The number of households

3. Old built-up area

黑松団地では土地分譫の注か建売り住宅や県党 アパートの建設がみられ，また，土地の分譲も2 年以内住宅を建築しな到ればならない条件が あるために，汪かの造成地より住宅地化が進展 している。この黑松団地 (2146人-1965・10・1現在) と民間による南光台 (2597人) との人口の年令別 構成を第 2 図炕示した。全体としては生産年令 層の多い都市型を示し，5歳未満が多いことも 新開住宅地の特色である。

しかし黒松では男子が 30 代 (264 人)，女子で は 20 代 (280人) が最も多く, 南光台は 20 代 の男子 (314人)が最も多い。ここにこれらの住 宅地成立の条件の差異があると予察される。

仙台に打ける丘陵地の宅地造成地では上下水 道施設の不備や道路の未舗装など, 環境の整備 に多くの問題が末解決のまま残されている。

(1966. 5.31 受理)

\section{文献}

田辺健一 (1962)：市街地の拡大と人口移動と の関係一仙台の例で一東北地理 14,79 84

Tanabe, K. (1963) : Housing Suburbs at the Northern Part of Sendai Sci. Reps. Tohoku Univ. (Geogr. ) 12 133 143

\title{
The Development of Housing Projects at the Hills in Sendai Tadashi SUGIMORI
}

Since 1955, the development of housing project: clearing the forests has particularly been remarkable in the north and south-westerm parts of the hills around the urbanized area of Sondai (Fig. 1). Those sites are classified into two types: One is with areas continuous from the peripheral part of old built-up area, and the other is a type in which nowly developed areas are separated from that.

Less than $10 \%$ of the capital invested for the development is public funds.

$\mathrm{Th}$ : differenses between public and non-public developments are shown in the age composition of population (Fig. 2). 